Portland State University

PDXScholar

1973

\title{
Life Cycle, Additions to Biology, and New Hosts of Apophallus Donicus (Trematoda: Heterophyidae) in Oregon
}

Delbert Raymond Niemi

Portland State University

Follow this and additional works at: https://pdxscholar.library.pdx.edu/open_access_etds

Part of the Biology Commons

Let us know how access to this document benefits you.

Recommended Citation

Niemi, Delbert Raymond, "Life Cycle, Additions to Biology, and New Hosts of Apophallus Donicus (Trematoda: Heterophyidae) in Oregon" (1973). Dissertations and Theses. Paper 1612.

https://doi.org/10.15760/etd.1611

This Thesis is brought to you for free and open access. It has been accepted for inclusion in Dissertations and Theses by an authorized administrator of PDXScholar. Please contact us if we can make this document more accessible: pdxscholar@pdx.edu. 
AN ABSTRACT OF THE THESIS OF Delbert Raymond Niemi for the Master of Science in biology presented May 18, 1973.

Title: Life Cycle, Additions to Biology, and New Hosts of Apophallus donicus (Trematoda: Heterophyidae) in Oregon.

APPROVED BY MEMBERS OF THE THESIS COMMITTEE:

Ralph /W Macy, Chairman

Richard Forbes

Leonard Simpson

Apophallus donicus is examined, its life cycle is described, and certain additions are made to its biology.

It is thought, but not proven, that eggs are eaten by the first. intermediate host, the local stream snail Flumenicola virens, and the miracidia escape internally. Mother and daughter rediae stages result, the later producing cercariae which are shed into the water. After burrowing just beneath the skin in suckers (Catostomus macrocheilus Girard), rainbow trout (Salmo gairdneri. Richardson), coho salmon (으corhynchus kisutch (Walbaum)), squan'fish (Ptychocheilus oregonensis Richardson), blackside dace (Rhinichthys osculus nubilus (Girard)), redside shiners (Richardsonius balteatus balteatus (Richardson)), and possibly other fish, the cercar- 
iae encyst and the resulting metacercariae cause black-spot disease in the host.

Natural definitive hosts were not found, but laboratory infections included gerbils, white rats, golden hamsters, chickens, catfish (Ictalurus punctatus (Rafinesque)), cats, and the author. A rainbow trout was found which had 33 immature Apophallus in its small intestine. All were alive and active, but their entire posterior ends, including all the sex organs, were degenerate and poorly formed compared to the anterior halves of their bodies, and there was no evidence that adults with eggs would have resulted. This trematode is very hardy and adaptable in all stages of its life cycle, e.g., cercariae lived and were active up until eight days after being shed, metacercariae remained infective in fish which had been dead and out of water for 60 hours, and adults lived in tap water at room temperature for 72 hours. 
IIFE CYCLE, ADDITIONS TO BIOLOGY, AND NEW HOSTS

OF APOPHALLUS DONICUS (TREMATODA: HETEROPHYIDAE)

IN OREGON

by

DELBERT NIEMI

A thesis submitted in partial fulfillment of the requirements for the degree of

MASTER OF SCIENCE

in

BIOLOGY

Portland state University

1973 
TO THE OFFICE OF GRADUATE STUDIES:

The members of the committee approve the

thesis of Delbert Niemi presented May, 1973.

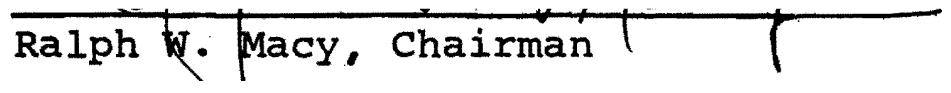

Richard Forbes

Leonard Simpson

APPROVED :

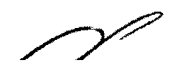

Earl Fisher, Head, Department of Biology

David Clark, Dean of Graduate studies

May, 1973 


\section{ACKNOWLEDGMENTS}

This work was supported by N.S.F. Grant GB-7923.

I wish to thank Robin G. Engiish for help in collecting specimens and for making certain microscopic preparations which were valuable in the description of parts of the life cycle.

Collecting equipment loaned by Dr. Charlie R. Powell, his aid in trapping specimens, and primarily his identifications of fish were very important and much appreciated. My gratitude also goes to Ray G. Sheldon of the Bonneville Fish Hatchery who gave me 50 salmon parr for in vitro infections. 
TABLE OF CONTENTS

PAGE

ACKNOWLEDGMENTS .............. . . . iii

IIST OF TABLES . . . . . . . . . . . . vii

LIST OF FIGURES . . . . . . . . . . . . viii

INTRODUCTION . . . . . . . . . . . . 1

TAXONOMY. .................. 2

Key to species of Apophallus by Price (1931). 5

Key to species of Rossicotrema by Ciurea

(1933). . . . . . . . . . . .

Key to the species of the genus Apophallus

Luhe, by.F.N. Morozov (Skrjabin, 1964). •. .

Key to the species of the genus Rossicotrema Skrjabin and Lindtrop, 1919, by F.N. Morozov (Skrjabin, 1964) .........

RESULTS

The life cycle of Apophallus donicus in

Oregon...................

Egg

Description and biology .......

Miracidium

Description and biology .......

Mother redia

Description and biology .......

Daughter redia

Description and biology . . . . . 
PAGE

Cercaria

Description . . . . . . . . . . 24

Cercarial biology . . . . . . . . . 27

Metacercaria

Description and biology . . . . . 30

Metacercarial biology . . . . . . 32

Adult

Description and biology . . . . . . 34

Results of certain experimental infections . 39

MATERIALS AND METHODS

Collecting fish . . . . . . . . . . 52

Collecting snails . . . . . . . . . . 53

Transporting fish and snails from the

field to the laboratory ........... 53

Maintaining animals in the laboratory . . . . 54

Obtaining metacercariae . . . . . . . . 55

Infecting laboratory animals with metacercariae .... . . . . . . . 56

Examining snails for cercariae . . . . . 58

Infecting fish with cercariae . . . . . 59

Excysting of metacerceriae . . . . . . . 61

Obtaining cultures of uninfected snails . . . 61

Attempts to infect Flumenicola virens
with eggs ....... 62

Shedding experiments . . . . . . . . . 62 
vi

PAGE

Microscopic preparations . . . . . . . 63

DISCUSSION AND CONCLUSIONS . . . . . . . . . . . 65

REFERENCES ................. 67 


\section{LIST OF TABLES}

TABIE

PAGE

I Comparative measurements of adult

Apophallus spp. . . . . . . . .

II Life cycles of each species of the genus

Apophallus . . . . . . . . . 49 


\section{IIST OF FIGURES}

FIGURES

PAGE

\section{PIATE I}

1 Arrangement of duct openings from penetration gland cells around the oral sucker in cercariae of Apophallus donicus. . . . . . . 41

2 Dorsal view of body of mature cercaria of Apophallus donicus . . . . . . . . . . 4 41

3 Mother redia of Apopha1lus donicus with daughter rediae inside .. . . . . . . . . 41

4 Cross section of a metacercaria of Apophallus donicus encysted in the tail fin of a coho salmon. ................4 4

5 External surface of daughter redia of Apophallus donicus showing anterior wrinkles. . . 41

6 Mature cercaria of Apophallus donicus between swims in resting position.... . . . . 41

7 Oral sucker of mature cercaria of Apophallus donicus showing spines and extruded lips . 41

8 Oral sucker of mature Apophallus donicus cercaria with lips in normal position. . . . 41

10 Newly shed daughter redia of Apophallus donicus. . . . . . . . . . . . . . . 41

\section{PLATE II}

1 Apophallus donicus èg, external surface . . 42

2 Apophallus donicus egg showing miracidium . . 42

3 Apophallus donicus adult, longitudinal section through acetabulum, genital sinus, and uterus ... . . . . . . . . . . . . . . 
4 Apophallus donicus daughter redia with cercariae. . . . . . . . . . . . . . 4 42

5 Arrangement of spines on the cuticular surface of Apophallus donicus cercaria. . . . . 42

6 Apophallus adult raised in rat from metacercaria from blackside dace, ventral view. -Possible new species . . . . . . . . . . 42

7 Possible Apophallus brevis adult raised in rat from blackside dace metacercaria, ventral view. . . . . . . . . . . . . 4 42

8 Apophallus donicus adult raised in rat from laboratory infection of coho salmon, ventral view................ . . . . 42

PIATE III

1 Apophallus donicus, ventral view . . . . . . 43

2 Apophallus donicus, ventral view . . . . . . 43

3 Apophallus lerouxi, ventral view . . . . . . 43

4 Apophallus muhlingi, ventral view. . . . . . 43

5 Apophallus imperator, ventral view . . . . . 43

6 Immature Apophallus americanus, ventral view . 43

7 Apophallus bacalloti, ventral view . . . . . 43 PLATE IV

1 Apophallus zalophi, ventral view . . . . . . 44

2 Apophallus bacalloti, ventral view . . . . 44

3 Metacercaria of Apophallus itascensis. . . . 44

4 Apophallus brevis, dorsal view . . . . . . 44

5 Apophallus venustus, ventral view. . . . . . 44

6 Apophallus crami, ventral view . . . . . . 44 


\section{INTRODUCTION}

All blackside dace from routine collections from Crystal Springs, in Portland, oregon, were found to have blackspot disease caused by encysted metacercariae. When these cysts were fed to a variety of laboratory animals, adult trematodes identified as Apophallus donicus Skrjabin and Iindtrop (1919) were found in the latter jejunum and the upper ileum of the small intestine.

Additional collections of blackside dace from Crystal Springs, Mill Creek at Salem, and Mill Creek at Turner, Oregon were all found to be infected. Redside shiners, squawfish, rainbow trout, coho salmon, and suckers from these locations were also almost universally infected. Flumenicola virens snails from these areas were found to contain pleurolophocercous cercariae, and by experimental infection of coho salmon, Gambusia spp., squawfish, blackside dace, and redside shiners, with subsequent feeding of cysts obtained to catfish, white rats, gerbils, golden hamsters, chicks, kittens, and the author, it was determined which among the several species of pleurolophocercous cercariae, was the one which would penetrate, encyst, and later produce adult Apophallus donicus.

Materials arid methods are discussed at the end of the thesis. Unless otherwise stated measurements are in microns. 
TAXONOMY

The taxonomy of Apophallus and related genera has been in confusion for many years. In 1898 Creplin misidentified a species found in Larus ribibundus from central Europe as Distomum lingus, and the following year it was renamed Distomum muhlingi by Jagerskiöld. Looss (1899) placed it in the genus Tocotrema, and Lühe (1909) made it the type species for his new genus Apophallus.

Skrjabin and Lindtrop (1919) created the genus Rossicotrema for $\underline{R}$. donicum from dogs and cats in Russia. Ransom (1920) described a new species from Larus delawarensis from Washington, D.C. under the name Apophallus brevis and in the same paper, created a new genus, Cotylophallus, for two c other new species, viz., ㄷ. similis from phoca vitulina and C. venustus from dogs, cats, and Vulpes lagopus. The material was all collected in the Washington D.C. area.

All four of the above species, irregardless of what genus they were placed in, were separated only on the basis of vitelline gland distribution. Ciurea (1924) transferred the species in the genus Cotylophallus to Rossicotrema. Cotylophallus had been created simply because Ransom was not aware of the erection of the genus Rossicotrema.

Szidat (1924) described Apophallus major from Larus fuscus in Europe. His new species was based solely on abso- 
lute measurements. This species was quickly refuted by Witenberg (1929) who reduced it to a synonym of Apophallus muhlingi. In this same paper, witenberg revised the family Heterophyidae. He examined a paratype of $\underline{A}$. brevis Ransom and decided that it, as well as Ransom's other two species, should be suppressed as synonyms of $\underline{R}$. donicum. Apophallus and Rossicotrema were still maintained as distinct genera divided by the position of the testes. They were tandem in Apophallus and oblique in Rossicotrema.

The term gonotyl was coined by witenberg (1929) to describe the genital papillae in the various Heterophyidae. He separated the genus Tocotrema with one gonotyl, from closely related Rossicotrema and Apophallus, both with two, on that basis. Later, Witenberg (1930) decided after restudying the available material, that the number of gonotyls was a specific rather than a generic character. With this in mind he supressed Rossicotrema in favor of Tocotrema. Meanwhile, other workers discarded Tocotrema in favor of Cryptocotyle. Witenberg did not agree with this and wanted both these genera kept." He separated them on the basis of body shape and location of the testes.

stunkard (1930) claimed that Tocotrema and Cryptocotyle should not be separated. By examining hundreds of specimens of $\underline{C}$. Iingua he showed that body shape and testes location were variable and could not be regarded as generic characters. He maintained that the previous suppression 
of Tocotrema was valid.

Price (1931) found Cryptocotyle and Apophallus to be valid genera. He separated them by the arrangement of their ventral suckers in relation to genital openings and gonotyls. Cryptocotyle has a spacious, somewhat muscular genital sinus with a very much reduced acetabulum on its anterior wall. The genital ducts open at the base of a single gonotyl which lies posterior to the ventral sucker. Tocotrema Looss, 1899, Hallum wigdor, 1918 and Ciureana Skrjabin, 1923, were included in this genus by Price. In Apophallus, the ventral sucker is well-developed and lies posterior to a small, weakly developed genital sinus with two papilla-like gonotyls. The genital openings are anterior to the acetabulum. Price included Rossicotrema Skrjabin and Lindtrop, 1919, and Cotylophallus Ransom, 1920, in the genus Apophallus. Yamaguti (1971) is in agreement with Price on these genera. 
KEY TO SPECIES OF APOPHALLUS BY PRICE (1931)

1. Body elongated, with more or less distinct constriction between acetabulum and bifurcation of intestine . . . . . . . . . 2

2. Vitellaria extend to level of acetabulum; intestinal bifurcation about one-third of body length from anterior end . . . . . . muhlingi

Vitellaria do not extend anteriorly as far as acetabulum; intestinal bifurcation about one-fifth of body length from anterior end crami

3. Body ovoid in shape; vitellaria extend to level of intestinal bifurcation or slightly beyond . . . . . . . . . . . . . donicus (including venustus and similis)

Body elongated pyriform in shape; vitellaria extend only slightly beyond acetabulum . . . . . . . . . . . . . brevis 
Van Cleave and Mueller (1932) described the species ${ }^{6}$ Apophallus americanus on two immature specimens from the intestines of fish. One came from a wall-eyed pike (Stizostedion vitreum) and the other from a yellow perch (Perca flavescens), both from Oneida Iake, New York. Price (1933) described Apophallus zalophi from Zalophus californianus. This species is small and thick, with large, closely packed vitellarian follicles which do not extend posterior to the testes. The prepharynx is longer than the esophagus and the seminal vesicle extends some distance forward of the acetabulum. All of these characters are different from those of other species of the genus Apophallus.

Ciurea (1933) removed this species from Apophallus and made it the type of the new genus, pricetrema. Ciurea also disagreed with Price about treating Rossicotrema and Apophallus as synonyms. He believed the shape of the body, the position of the testes, and the way the metacercariae developed constituted generic difference. Ciurea maintained that $\underline{R}$. donicum, $\underline{R}$. venustum, and $\underline{R}$. $\underline{\text { simile were valid }}$ species, distinguished by the anterior extent of distribution of the vitellaria. 
KEY TO SPECIES OF ROSSICOTREMA BY CIUREA (1933)

Yolk follicles reach almost to level of bifurcation of esophagus................

Yolk follicles pass in front of level of bifur-. cation of esophagus................ R. simile

Yolk follicles do not reach the level of bifur-

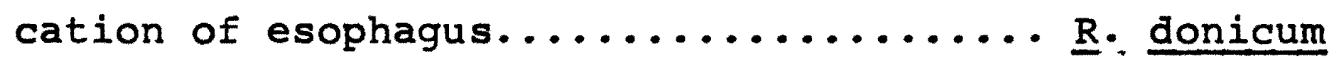


In the key Ciurea used to divide these species, his last statement about $\underline{R}$. donicum is in direct contradiction to the original description by Skrjabin. Here Skrjabin said, "the forward border of the vitellaria pass by at the level of the transition of the esophagus into the intestine." If Ciurea were indeed working with $\underline{A}$. donicus, then $\underline{A}$. brevis could not be a valid species. This is because $\underline{A}$. donicus would include the characters that separate it from $A$. brevis.

Africa and Garcia (1935) described Apophallus eccentricus from a Philippine dog. This species had a long prepharynx, a genital pore latero-dorsal to the acetabulum, a uterus extending into the posterior region of the body and vitellaria which extended only barely past the ovary. I agree with Cameron that these characteristics exclude it from Apophallus.

At this time the species donicum, brevis, venustum, and similis had been placed in three genera by various authors. This caused much confusion. If there had been one set of generic criteria for separating, or combining, Apophallus, Rossicotrema, Cryptocotyle, and Tocotrema, part of the confusion would have been avoided. Witenberg regarded the distribution of the vitellaria and the relative position of the testes important enough to separate these genera. He put all of the four species mentioned in the genus Tocotrema as synonyms under the name $\underline{T}$. donicum. He 
thought the presence of one or two gonotyls and the opening of the genital ducts to be only of specific importance. Ciurea (1933) thought the shape of the body, the development of the metacercaria, and the position of the testes were the three important generic characters. He felt that the acetabulum-gonotyl relationship had more than generic importance. He recognized all of the four above species as valid and placed brevis in the genus. Apophallus and the other three in the genus Rossicotrema. Price considered "the genital sinus and the arrangement of its accessory structures" to be the most important generic criteria. Price placed venustus and similis in the genus Apophallus as synonyms of the species A. donicus. He . recognized only two valid species; $\underline{A}$. donicus and $\underline{A}$. brevis. There was even more confusion in differentiating the species. A. crami. A. muhlingi and the four species mentioned above are differentiated on characteristics which are variable, and also very subtle. The main point of variance seems to have been vitellarian distribution up to this time.

This is the criterium that cameron (1936) used to justify the species $\underline{A}$. venustus. He divided the species in the genus Apophallus as follows:

1. Yolk glands do not reach level

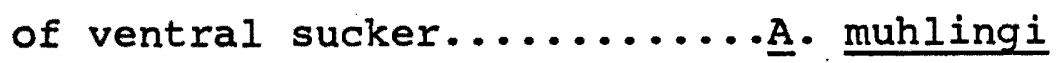
A. donicus A. 
"In this group, ․․ muhlingi has a narrow body with testes almost tandem; in A. donicus the body is oval to pyriform with the testes oblique; in $\underline{A}$. brevis, the body is elongated pyriform and the testes oblique."

2. Yolk glands reach level of esophageal bifurcation................. venustus (including c. similis)

Cameron also claimed venustus and donicus differed in the position of the testes. "In the former they are always distinctly oblique, more or less spherical and fairly posterior; in the latter, they tend towards a side-by-side arrangement, although generally distinctly oblique, are more or less triangular in outline and occupy a slightly more anterior position in the body. ․․ donicus has a maximum length of $1.4 \mathrm{~mm}$ and width of $0.55 \mathrm{~mm}$. The eggs of ㅅ․ donicus are slightly larger than those of A. venustus (35-40 by $19-24$ and $26-32$ by $18-22$ respectively)."

Cameron agreed with Price about similis being a synonym of venustus, but not in regarding venustus as a synonym of donicus. Cameron (1937) showed that $\underline{A}$. venustus encysted in the musculature of catfish and migrated there through the blood vessels from an entry point in the fins or tail. This he contrasted with Ciurea's description of R. donicum (A. donicus) which encysted only in the fins in light infections, and with heavy infections, in the skin, under the scales, and in the fins. In the fins they are 
found usually inside the rays and rarely in the membranes.

Apophallus imperator was described (Lyster, 1940) from adults taken from cats and pigeons, which had been fed metacercariae-infected salvelinus fontinalis. The fish intermediate hosts were taken in the Province of Quebec, Canada. Lyster tried to justify this species on the basis of the microstructure of the gonotyls. Miller (1941) refuted this species because he said the appearance of the gonotyl was not "sufficiently significant or constant to be of specific importance." He reduced $\underline{A}$. imperator to a synonym of $\underline{A}$. brevis. This I agree with.

Morosov (1952) named A. bacalloti from a description by Balozet and Callot (1939) of a trematode found in the intestine of Botaurus stellaris in Tunisia. He separated this species from $\underline{A}$. muhlingi, which it closely resembles, by its smaller size, the anterior extent of its vitellaria, and the small number of eggs found in its uterus. The prepharynx is also longer than most other species in the genus Apopha1lus.

Warren (1953) described Apophallus itascensis from the perch, Perca flavescens, in Minnesota. This species was described from the metacercariae alone. Warren separated itascensis from other members of the genus solely on the shape and size of the metacercarial cysts and the host he found them in.

Finally, Rayski and Fahmy (1962) described $\underline{A} \cdot \underline{\text { lerouxi }}$ 
from Tringa totanus totanus in Eastern Scotland. From their description and drawing, the species looks very similar to $\underline{A}$. brevis except that the eggs are a little smaller, and they mention a cirrus sac. If this latter statement is fact, I agree with Yamaguti (1971) in that this species should not be included in Apophallus. 
KEY TO THE SPECIES OF THE GENUS APOPHALLUS LUHE, BY F. N. MOROZOV (SKRJABIN, 1964)

1(10) Vitellaria not extending anteriorly beyond level of ventral sucker.

2(7) Vitellaria not confluent posterior to testes.

3(6) Vitellaria extending beyond testes.

4(5) Intestinal bifurcation equatorial.

A. imperator Lyster, 1940

5(4) Intestinal bifurcation at end of first third of body. A. muhlingi (Jagerskiold, 1899)

6(3) Vitellaria not extending beyond testes; intestinal bifurcation at two-fifths of body length from anterior end.

A. bacalloti (Balozet and Callot, 1939)

7(2) Vitellaria confluent posterior to testes.

8(9) Intestinal bifurcation nearly equatorial.

A. americanus Van Cleave and Mueller, 1932

9 (8) Intestinal bifurcation at one-fifth of body length from anterior end.

A. Crami Price, 1931

10(1) Vitellaria extending slightly anterior to ventral sucker. A. brevis Ransom, 1920 
KEY TO THE SPECIES OF THE GENUS ROSSICOTREMA SKRJABIN

AND LINTROP, 1919, BY F. N. MOROZOV (SKRJABIN, 1964)

1(2) Vitellaria lateral, disjunct at levels of transverse vitelline duct, forming two groups on each side of body; testes sub-equal.

R. donicum Skrjabin and Lindtrop, 1919

2(1) Vitellaria continuous; transverse diameter of left testis two times larger than diameter of. right testis.

R. venustum Ransom, 1920 
RESULTS

THE LIFE CYCLE OF APOPHALLUS DONICUS IN OREGON

The life cycle worked out in this study of Apophallus donicus is as follows. It is thought, but not proven, that eggs are eaten by the first intermediate host, the local stream snail Flumenicola virens, and the miracidia escape internally. It is not known what happens immediately after this, but the miracidia eventually reach the digestive gland of the snail, and mother and daughter rediae stages result.

Daughter rediae produce cercariae which are shed periodically into the water surrounding the snail. These cercariae attach to the surface of any of a wide variety of fish in the area. Fish known to be suitable second intermediate hosts are suckers (Catostomus macrocheilus Girard), rainbow trout (Salmo gairdneri Richardson), coho salmon (으corhynchus kisutch (Walbaum)), squawfish (Ptychocheilus oregonesis Richardson), blackside dace '(Rhinichthys osculus nubilus (Girard)), and redside shiners (Richardsonius balteatus balteatus (Richardson)).

After burrowing beneath the skin, but not into the musculature of such fish, the cercariae encyst and metacercarial cysts result. These cysts cause black spot disease 
in fish, which results in an accumulation of pigment in these areas of infection.

All mammals and birds which were fed the metacercarial cysts of $\underline{A}$. donicus became infected with the adult trematode. Although natural definitive hosts were not found, laboratory infections included gerbils, white rats, golden hamsters, chickens, catfish (Ictalurus punctatus (Rafinesque)), cats, and the author. One naturally infected, although probably unnatural, host was found. This was a rainbow trout $12 \mathrm{~cm}$ long which had 33 immature Apophallus in its small intestine. All were alive and active, but their entire posterior ends, including all the sex organs, were degenerate and poorly formed compared to the anterior halves of their bodies. This was much the same circumstance that was found by Van Cleave and Mueller (1932), when they described the species $\underline{A}$. americanus from fish. 
EGG

\section{DESCRIPTION AND BIOLOGY}

The eggs of Apophallus donicus are a brownish-gold when they leave the adult trematode, and are shaped roughly like a Grecian amphora with a slight acentric tilt (Plate II, figs. 1 and 2). They are 32 (21-33) long, and 18 (17-20) wide with a hemispherical-shaped operculum 8(8-8) in diameter.

The posterior end of the egg many times has a thickening, a tiny spine, or a nodule on it. The surface of the egg, when it is shed, is completely covered with what appears to be cracks spreading in a honeycomb pattern. The shell itself is rather pliable and will stretch, causing the egg to flatten out when subjected to pressure from a coverglass. Even with intense pressure, i.e., a $3 \mathrm{~kg}$ weight on the coverslip, the operculum will not pop open, nor will the egg otherwise burst.

Eggs found in passed feces have active miracidia inside. When placed on a slide, these miracidia are not killed by pressures of up to $1 \mathrm{~kg}$ of weight on the coverslip, with nothing but eggs and a minimal amount of distilled water under it. 


\section{MIRACIDIUM}

\section{DESCRIPTION AND BIOLOGY}

The miracidia are fully formed and active within the egg by the time eggs appear in an animal's feces. They measure 13 (12-14) long and 24 (22-25) wide and are roughly teardrop-shaped with the small end, or point, directed toward the operculum of the egg.

All attempts to free miracidia artificially by opening eggs in various mechanical ways were unsuccessful. In two instances when eggs were finally broken open, the miracidia were killed and so damaged that they could not be further studied.

In the natural course of the life cycle, I think that eggs containing miracidia are scraped up and eaten by the stream snail Flumenicola virens with the snail's natural diet of diatoms. This is the case with other species in the genus Apophallus where the life cycle is known (Cameron, 1933). Although some snails were observed to voluntarily eat eggs that they were exposed to, no empty egg shells were found in the snail feces.

I was unable to substantiate under laboratory conditions that eggs eaten by Flumenicola virens would hatch internally. This, however, is the case with $\underline{A}$. venustus. 


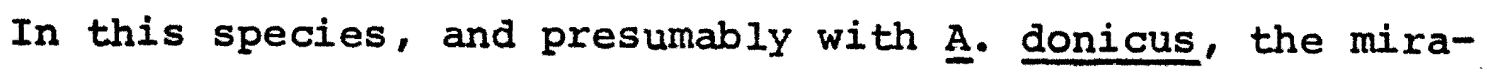
cidia are liberated internally, migrate to the digestive gland, and there develop into mother rediae. 
MOTHER REDIA

\section{DESCRIPTION AND BIOLOGY}

Mother rediae were found in snails with natural infections only in the spring and early summer. The mother rediae were quite numerous in the digestive glands of the snails, but were never found without some independent daughter rediae.

The pharynx of the mother redia is 27 (24-32) long and $25(23-31)$ wide. The cecum is very tiny, sometimes no larger than the pharynx, to which it is connected by a short esophagus. The redia body is 355 (292-396) Iong, 146 (130161) wide, with evident excretory tubules along its surface and some visible flame cells at the time it is ready to shed cercariae.

The anterior ends of the rediae are bulbous and usually only slightly larger than the pharynx. The body is rather sausage-shaped and always curved when the mother rediae are young. As the daughter rediae begin to mature inside, the mother rediae become more irregular in shape with bulges and constrictions. Daughter rediae reach maturity at different times and there is a gradation from immature daughter rediae posteriorly to mature ones anterior in the bodies of the mother rediae. Numbers of daughter rediae varied, but were always large. Recognizable daughter rediae, as opposed to germ 
cell clumps, average about 15 per mother redia.

No birth pores were found, but since the daughter rediae matured at different times, one may well be present. 
DAUGHTER REDIA

\section{DESCRIPTION AND BIOLOGY}

Daughter rediae were found in snails the year around. In the middle and late summer they were found in up to $43 \%$ of individual Flumenicola snail samples taken from Crystal Springs in Portland. They never were found in less than $5 \%$ of snails opened at any time of the year. In infected snails the digestive gland is almost entirely filled with a sluggish, squirming mass of daughter rediae.

Daughter rediae leave the mother rediae when they are between 80 and 100 in length, and their pharynx is already 30 (29-33) long and $31(28-36)$ wide. The pharynx does not grow larger after they are released from the mother redia. The body is shaped much like that of the mother redia when it is young, although it is usually longer 485 (358-982), and thinner 140 (108-166).

The anterior part of the daughter redia is bulbous, much like the mother redia, and the cecum and the esophagus are very small. The exterior of the anterior daughter redia is concentrically wrinkled from the anterior end for $1 / 5$ to $1 / 7$ of the distance to the posterior tip of the body (Plate I. fig. 5) .

There is a gradation in the maturity of cercariae from 
germ balls concentrated in the posterior end to cercariae ready for release in the anterior part of the daughter rediae bodies. No birth pores were found in any of the daughter rediae examined. In many mature specimens, cercariae nearly ready to be shed were found in various parts of the redia body instead of being concentrated in the very anterior end. Possibly when the cercariae reach maturity they begin to migrate inside the daughter rediae. The bodies of these rediae were constricted along their length like a string of link sausage. The constrictions may represent areas that excaping cercariae have left vacant. 


\section{CERCARIA}

\section{DESCRIPTION}

Pleurolophocercous cercaria. Body surface covered with scale-like spines from the extreme anterior end to roughly $2 / 3$ of the distance to the partially subterminal ventral attachment of the tail. Spines arranged in a dense, regular, almost imbriated form anteriorly, becoming smaller, more sparse, and less closely arranged toward the posterior end of the body. Exposed portions of anterior scales are roughly triangular, and arranged 1.5 apart in any planar direction. The bases of these triangles which are attached to the body surface are 0.8 wide, as are the two exposed sides of the spines. Tail slender, 26 (23-35) wide, 358 (332-370) long, with a continuous dorsal and ventral fin. Fin originates 51 (46-58) from the body on the dorsal surface of the tail, flares again to $15(13-18)$ before it rounds the tip of the tail. The fin is sword-shaped at the end of the tail, and is supplied with two permanent plicae (or possibly reinforcing ribs). The fin extends 10 (9-12) past the tip of the tail, flares again on its ventral course to $18(15-22)$, and at 85 (72-101) tapers rapidly, terminating 115 (103-140) from the tip of the muscular tail. 
Other transient plicae are distributed at high points in the fin where support is most lacking. Muscle fibers in the tail run at an oblique angle dorso-ventrally and near the body the tail surface is convoluted for 102 (88-120) toward its tip.

Oral sucker subterminal, unarmed, but with several rows of tiny curved spines arranged as cutting edges on the dorsal and ventral lips. The dorsal portion of the sucker is much more muscular and thick than the ventral section. On the dorsal lip of the sucker are three rows of spines, a fourth is arranged on the fleshy portion of the anterior body which overhangs the oral sucker, and a fifth is on the ventral lip of the oral sucker (Plate I, figs. 7 and 8). Sucker length is 43 (34-48), height is $23(20-29)$ and width is $30(25-44)$. Ducts from 14 single-celled penetration glands empty on the dorsal and dorso-lateral margins of the partially protrusible sucker.

The lips of the sucker are very active. The musculature must be very complex because the cercariae seem to be able to move them in a variety of contortive motions. Between swimming movements the cercariae partially evert the oral sucker and grope about with their lips, apparentIy able to explore the environment in this manner.

The sperical pharynx is poorly developed, and difficult to distinguish in most specimens. It is situated ventral and slightly posterior to the eye spots, and the 
ducts of the penetration glands collect into one large bundle dorsal to it on their course from the gland cell bodies. In some cercariae, possibly due to age, duct enlargements resembling storage sacs appear along these ducts at the posterior margin of the oral sucker. The ducts enter these areas in two bundles and pass forward as four. The two dorsal bundles have four ducts while the two latero-dorsal ones each have three. (The arrangement of duct openings are diagrammed in Plate I, fig. 1.)

The penetration glands are arranged in one large cluster and occupy a large portion of the central cercarial body. They are unicellular, guite large (up to 15 in diameter) and have large, prominent, single nuclei. The excretory vesicle is thick-walled, large 30 (25-44) with a $\mathrm{V}$ or Y shape. Tan-orange pigment and granular material with much Brownian movement is evident in pockets in all parts of the body, making internal structure difficult to observe. Flame cells and excretory ducts are seldom seen, especially in older specimens. The older the cercariae, the more pronounced the pigmentation.

The cercariae of $\underline{A}$. donicus lack the protoplasmic extensions found in cercariae of other Apophallus spp. for which the life cycles have been worked out (Cameron, 1937, Miller, 1940, Odening, 1970). Numerous cystogenous glands are scattered throughout the cercarial body. There are about eight gland cells associated with the base of the tail 
which may have something to do with releasing the tail from the body as the cercariae begin to penetrate fish.

Eye spots are located 10 (9-14) from the sides of the body and 60 (50-82) from the anterior tip. They vary somewhat in shape, size, and intensity of pigmentation. Some cercariae appear devoid of eye spots until closely examined. It is then found that the pigmentation is very sparse, although the size of the eye spots are normal 8 (7-10) wide by 7 (6-9) long. Sometimes the right eye spot, as viewed dorsally, may be hourglass-shaped. Both usually are roughly rectangular.

\section{CERCARIAL BIOLOGY}

In an environmental chamber set for 12 hours of daylight and a continuous temperature of $17^{\circ} \mathrm{C}$ individual snails shed up to 2,380 cercariae in 24 hours. Numbers of cercariae shed reached peaks between 7:00 and 9:00 A.M. and 7:00 and 9:00 P.M. During the middle of the day and during most of the dark hours, little or no shedding occurred. In clean, dechlorinated tap water at $17^{\circ} \mathrm{C}$, cercariae lived and were active up until eight days postshedding. Swimming movements are rapid and the tail beats clockwise in an elliptical figure-8 pattern. The last 100120 of the tail flexes ventrad in the fraction of a second just before initiation of swimming motions, to an angle of about $120^{\circ}$ with the rest of the tail to give an added initi- 
al thrust. Although the tail as a whole describes a clockwise figure-8 when swimming, the tip paddles somewhat independently in a different plane. Slow-motion moving picture studies would facilitate understanding of the details of this tail action. The cercariae at rest in the water resemble the shape of the letter $J$ or the curve of a pipe stem.

When cercariae are placed in a confined space with a fish (e.g., a $6 \mathrm{~cm}$ salmon in a petri dish of water), attachment of the oral sucker to the fish is very rapid, in as little as 10 seconds, and shed tails begin to appear in as short a period as 25 seconds. When a cercaria once attaches to a suitable host, no amount of movement by the fish seems to dislodge it. After contacting the surface of a fish in any location, even on the surface of the eye, cercariae continue violent movement with their tails without stopping until the tail is finally lost. Tails continue to beat independently, finally resuming the normal periodic beats and rest periods. Such tails may remain active for several hours. The cercariae spend 8 to 20 minutes penetrating the integument of the fish, migrate a short distance, and round up just under the skin.

Salmon were unable to withstand an attack by large numbers of these cercariae and as few as $35 \mathrm{killed} 6 \mathrm{~cm}$ salmon when administered simultaneously. Young salmon, trout and other fish could be killed or seriously impaired, at least long enough to make them easy prey to predators, if 
they ventured past a heavily shedding snail in their natural environment. One heavily infected trout was observed to swim in a corkscrew pattern, possibly due to some damage to its lateral line system by invading cercariae.

On the other hand, in a 5 gallon aquarium of water, one heavily shedding snail did not noticeably damage the fish. Occasional penetrations by cercariae eventually accounted for more metacercarial cysts than when fish were exposed to massive numbers in a small container. The gradual dosage may have slowed or impaired the fish slightly, but gross effects in their behavior were not evident.

When cercariae were placed with Gambusia spp., the result was different. If the fish had not been subjected previously to these cercariae, they were able to penetrate the integument of the fish and partially enter through the hole. There seems to be an allergic reaction, however, with a large swelling resulting at each point of penetration. The cercariae did not form cysts, even when they penetrated Gambusia spp. With subsequent exposure of previously exposed fish the cercariae without exception were not able to penetrate. It seems that previously exposed fish can illicit an immune response to Apophallus donicus. 


\section{METACERCARIA}

\section{DESCRIPTION AND BIOLOGY}

Metacercarial cysts were always found just beneath the skin in the fascia, and never in muscle tissue. Fins, tails, and adipose fins are favorite areas of attack by cercariae, with subsequent encystment. In fins and tails cysts were almost never found in the fin rays, as reported by Ciurea (1928) for Apophallus donicus, and Cameron (1937) for $\underline{A}$. venustus, but just under the skin in the interradial membranes.

In natural infections of fish the numbers of cysts varied greatly, due to locality, age of the fish, and time of the year. Blackside dace $6 \mathrm{~cm}$ long were found with up to two hundred cysts from natural infection. In artificial infections of coho salmon, which were exposed to a number of cercariae each day over a three week period of time, one fish $9 \mathrm{~cm}$ long was found to have 85 cysts in the tail fin alone.

The oval cysts measure 103 (93-108) in diameter, 145 (138-162) in length, had outer fibrous walls 4 (3-6), and inner hyaline walls $0.5(0.3-0.9)$ thick. In infections of long standing, increasing amounts of pigment occurred around cysts, causing conspicuous black spots. Fish thus affected seemed to prefere dark areas of the tanks and 
their total body color remained much darker than uninfected fish in the same tank. When exposed to bright light over a long period of time, fish infected for over one month did not attain a hue as light as uninfected fish, even in parts of the body with no cysts. This could constitute a great handicap to survival for a fish in the wild.

The encysted metacercariae are doubled on themselves, not only from anterior to posterior, but from side to side in some specimens. Others with more room, possibly younger metacercariae, do not have lateral folding. The metacercariae are able to move freely in the cyst and do so regularly.

Excysted metacercariae are oval to shoe-sole-shaped, and 305 (290-361) long by 139 (128-162) wide. The anterior three fourths of the body is covered with fine spines. The oral sucker is $36(33-40)$ long by 41 (38-50) wide. The acetabulum is $27(24-30)$ long, 28 (24-31) wide, and not nearly as muscularly well-developed as the oral sucker. Two fleshy gonotyls are visible just anterior to the acetabulum in the genital sinus in some specimens.

The spherical ovary is poorly developed and its outline is a rather vague $29(26-32)$ long and $28(26-31)$ wide. Right and left testes are both spherical, rather poorly defined, equal in size $31(29-36)$ and are situated with the left one rather anterior to the right one in the posterior one sixth of the body.

The prepharynx is very short to non-existant. The 
pharynx is $23(20-28)$ long and $24(20-29)$ wide. The esophagus reaches very near the center of the body before it bifurcates into the two thin intestinal ceca. The ceca pass along the lateral edges of the body to very close to its posterior tip.

The metacercariae have $\mathrm{Y}$ or $\mathrm{T}$-shaped excretory bladders which pass between the testes as a single tube and bifurcate anterior to them. Two large tubules leave the excretory bladder at the tips of these bifurcations and pass anterior along both sides of the body to very near the oral sucker. Hsu (1936) worked out the metacercarial flame cell pattern for $\underline{A}$. donicus as $2((2+3)+(3+2$ $+3)$ ). I was not able to verify his results.

\section{METACERCARIAL BIOLOGY}

Metacercariae are infective four weeks after cercariae penetrate the epidermis of the second intermediate host when kept at a constant $17^{\circ} \mathrm{C}$. Metacercariae up to nine weeks of age at $6{ }^{\circ} \mathrm{C}$ did not produce adults when fed rats in six infections. Therefore, temperature must be an important influence to the speed of development.

There seems to be a correlation between infective rate and the hosts diet. Animals maintained on a vegetarian diet produced fewer specimens per infection, kept them shorter periods of time, and produced smaller adult parasites with fewer eggs. Also, time to maturity 
was lengthened in these hosts.

An abrupt change in diet sometimes freed the host of its infection, especially if the diet was changed from fish to vegetable, in the form of dried cereal cubes. 


\section{ADULT}

DESCRIPTION AND BIOLOGY

Body oval, pyriform, or somewhat linguiform, 381 (298-554) long and $262(186-303)$ wide, when slightly flattened under a cover glass. When alive and at rest, the anterior half of the body is flattened dorso-ventrally while the posterior part behind the acetabulum is much less flattened. In linguiform specimens there is a constriction just anterior to the acetabulum.

The anterior body surface is covered with tiny scalelike spines. The portion of each spine which protrudes through the cuticle is a posteriorly directed triangle, 1 long and 2 wide. Looking at the spines from on edge, each is curved posteriorly, with 1 exposed and 5 embedded. The exposed portions of the spines have an imbricated arrangement and are set 2 apart laterally and longitudinally. Between the spines are uniformly dispersed openings for large secretory or sensory cells which stain very heavily in some specimens.

The oral sucker is subterminal, 60 (53-69) in diameter, and $52(45-62)$ in length. The acetabulum is 40 (32-46) long, $42(36-45)$ wide, situated equidistant from the sides of the body, but usually some distance anterior 
to the longitudinal midpoint. The acetabulum is ventral and posterior to the genital sinus. The sides of the sinus are guarded by two fleshy spherical or ovoid gonotyls. The genital pore opens at the anterior end of the sinus from a duct, common to both the male and female reproductive systems, which leads from the left side of the body. The duct from the seminal vesicle empties into the oviduct approximately 10 from the genital opening.

The seminal vesicle is bipartite. The left lobe, 18 (9-42) long by $26(12-61)$ wide, is ventral and anterior to the right lobe, $21(12-31)$ long by $54(50-60)$ wide. Normally this organ is filled with active sperm two days after metacercarial cysts are eaten by the definitive host.

The seminal receptacle is oblong or bean-shaped and is wedged posteriorad, ventrad, and mesad to the ovary and anterior to the right testis. The vesicle is $30(22-42)$ long and 48 (33-70) wide and the medial end tapers into the tube which leads to Mehlis' gland. After 60 hours inside the definitive host the seminal receptacle is normally filled with active sperm cells. In older trematodes the number of sperm stored in this organ did not seem to diminish.

The prepharynx is very short $4(0-7)$, and in some specimens it is not apparent at all. The pharynx is round, oval, or oblong, very muscular, and is situated dorsad as well as posteriad to the oral sucker. Its dimensions are 
$29(27-34)$ long and $30(26-33)$ wide.

The esophagus is long, $40(21-60)$, slender, and bifurcates one-fifth to one-third of the body length from the anterior end into the intestinal ceca. The intestinal ceca branch from the esophagus anterior to the acetabulum into two equal-sized, narrow tubes which course immediately to the lateral edges of the body. They pass to a level very near the posterior extremity of the body. When Apophallus donicus is in less than a 0.858 saline solution the ceca and the excretory bladder swell to many times their normal diameters. Sometimes it is possible to see food streaming from one cecal branch to the other in living specimens. No food particles appear to pass back up the esophagus unless the animal permits this by opening the pharynx which is normally tightly closed.

The testes are approximately the same size. The left testis, length $78(60-92)$, width $92(75-104)$, is dorsal as well as to the side of the right testis, length 80 (67-113), width 95 (85-121). The testes are located in the posterior $1 / 3$ of the body and they are at an oblique angle from each other with the left testis usually $1 / 3$ to $1 / 2$ of its width anterior to the right one.

The ovary is usually roughly spherical or oblong, 52 (35-72) long and $66(50-86)$ wide, but occasionally, it is a rectangular or pyriform organ.

The vitellaria occupy nearly all available space from 
the most posterior extremity of the body to a level just anterior to the bifurcation of the intestinal ceca. The vitellarian follicles are of various sizes and shapes with no uniformity or even dispersal, although their heaviest concentrations are lateral to the ceca. They also densely occupy the area surrounded by the bifurcating ceca and the acetabulum, which is unusual for members of the genus Apophallus. In most other species this area is free of vitellaria.

The eggs do not begin to appear in the oviducts of A. donicus until at least 60 hours after metacercarial cysts have been eaten. This appearance of eggs can be delayed as long. as 7 days by the diet of the host, type of host, i.e., whether it is a bird or mammal, what species of bird or mammal it is, and possibly other factors. These might include the sex of the animal, the structure of the intestinal lining, whether the animal is normally a vegetarian, carnivore, or a scavenger, and maybe even the time of the year the cysts are eaten.

The excretory system of Apophallus donicus consists of a large excretory bladder, a system of excretory tubules which empty into the bladder, and flame cells which are scattered throughout the trematode body. The flame cell pattern was not worked out. It seems that it should not vary from the metacercarial formula worked out by Hsu (1936). The bladder is Y-shaped with a sigmoid stem squeezed tightly 
between the testes. Two large tubules leave the bladder at the most anterior extent of the arms of the bladder. These tubules extend anteriorly almost to the oral sucker. In their forward extension they pass down the sides of the body and collect excretory material from small ducts which come from the flame cells. 
RESULTS OF CERTAIN EXPERIMENTAL INFECTIONS

In attempts to infect Flumenicola virens with eggs from adult Apophallus donicus, 30 eggs were observed to be eaten by 5 snails. No evidence was found to substantiate the possibility that these eggs hatched inside the snails or led to any further stages in the life cycle.

$T_{\text {he snails did well for three weeks and then all died }}$ of fungus infections. Upon autopsy, no trematode stages were recognized. No further attempts were made to infect snails.

A. donicus eggs that were left in distilled water for up to 6 weeks at $17^{\circ} \mathrm{C}$ did not hatch. The miracidia, however, remained alive and active inside the eggs the entire time.

From examination of fecal samples taken from the human infection it was found that eggs began being passed 8 days postinfection. Small numbers of eggs were found until the 23rd day. No subsequent examination of feces proved positive for $\underline{A}$. donicus eggs.

In kittens the first eggs were passed in 7 days. No adults were found, however, when infected kittens were sacrificed after 14 days, although eggs were found in the feces the previous day.

When certain cysts from blackside dace were fed to white rats, specimens of two species of Apophallus adults were re- 
covered. Tentatively, they were identified as $\underline{A}$. brevis and an undescribed species of Apophallus. The taxonomy of this genus will be re-evaluated when current work on these species is completed. 
Figure 1. Arrangement of duct openings from penetration gland cells around the oral sucker in cercariae of Apophallus donicus. (original)

Figure 2. Dorsal view of body of mature cercaria of Apophallus donicus. (original)

Figure 3. Mother redia of Apophallus donicus with daughter rediae inside. (original)

Figure 4. Cross section of a metacercaria of Apophallus donicus encysted in the tail fin of a coho salmon. Abbreviations: fr-fin ray; pc-pigment cell; mc-metacercarial cyst; st-scar tissue. (original)

Figure 5. External surface of daughter redia of Apophallus donicus showing anterior wrinkles. (original)

Figure 6. Mature cercaria of Apophallus donicus between swims in resting position. (original)

Figure 7. Oral sucker of mature cercaria of Apophallus donicus showing spines and extruded lips. (original)

Figure 8. Oral sucker of mature Apophallus donicus cercaria with lips in normal position. (original)

Figure 10. Newly shed daughter redia of Apophallus donicus. (original)

All figures measured in $\mathrm{mm}$. 


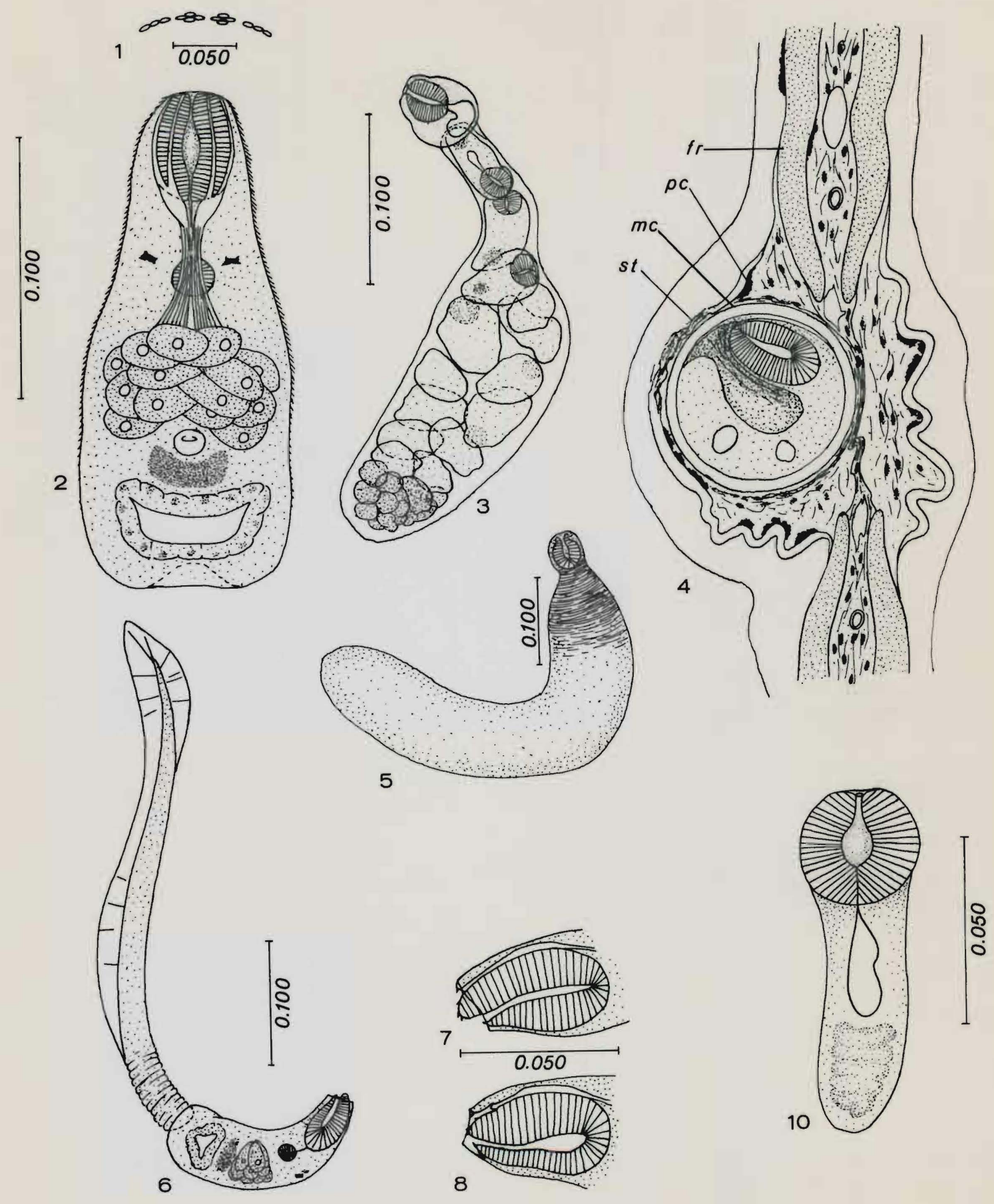


Figure 1. Apophallus donicus egg, external surface. Figure 2 (original) Apophallus donicus egg showing miracidium.

Fiqure 3. Apophallus donicus adult, longitudinal section through acetabulum, genital sinus, and uterus. Abbreviation: g-gonotyl. (original)

Figure 4. Apophallus donicus daughter redia with cercariae. (original)

Figure 5. Arrangement of spines on the cuticular surface of Apophallus donicus cercaria. (original)

Figure 6. Apophallus adult raised in rat from metacercaria from blackside dace, ventral view. Possible new species. (original)

Figure 7. Possible Apophallus brevis adult raised in rat from blackside dace metacercaria, ventral view. (original)

Figure 8. Apophallus donicus adult raised in rat from laboratory infection of coho salmon, ventral view. (original) 

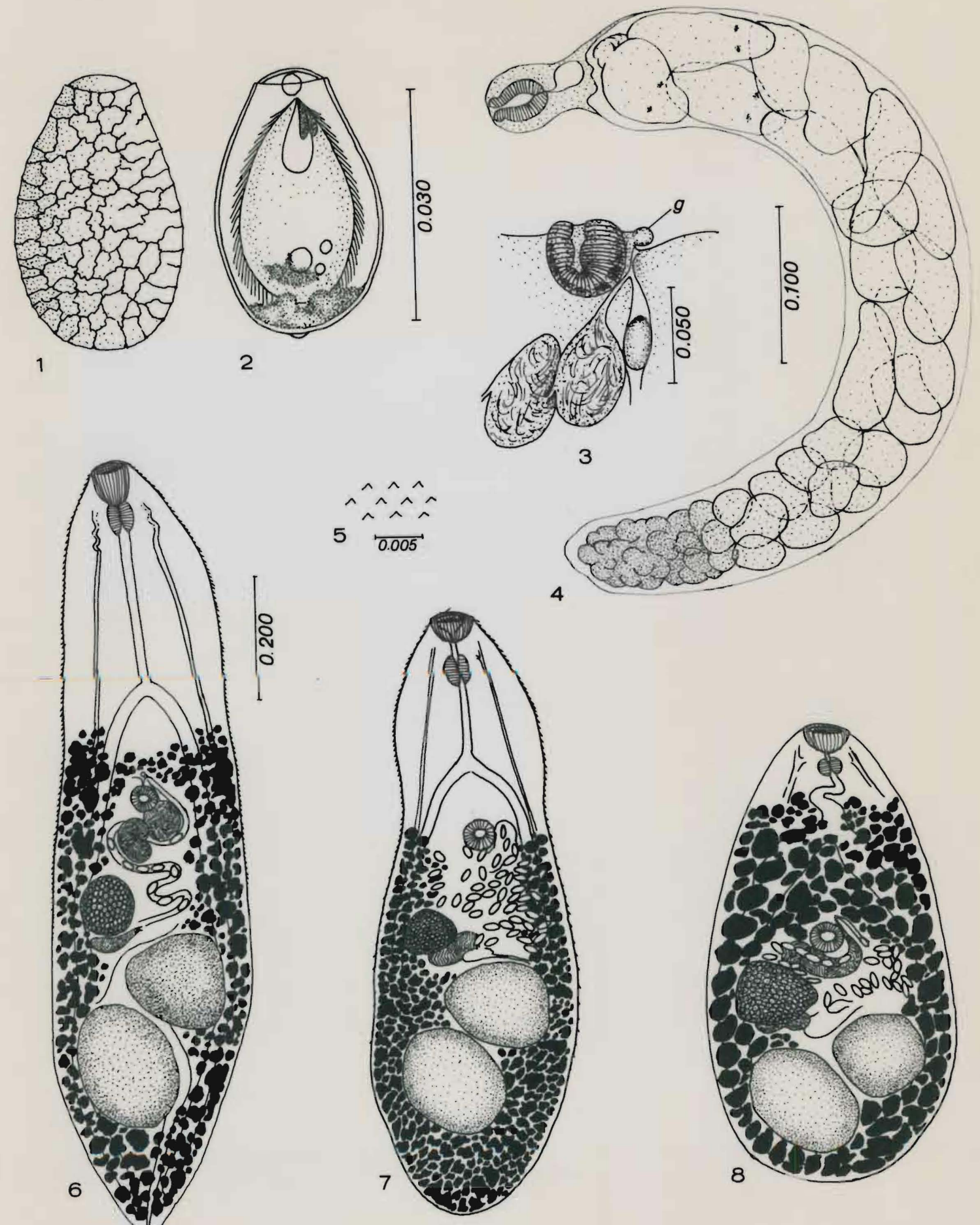
Figure 1. Apophallus donicus, ventral view. (redrawn from Skrjabin, 1964; from Skrjabin and Lindtrop, 1919)

Figure 2. Apophallus donicus, ventral view. (redrawn from Skrjabin, 1964; from Cuirea, 1934)

Figure 3. Apophallus lerouxi, ventral view. (redrawn from Layski and Fahmy, 1962)

Figure 4. Apophallus muhlingi, ventral view. (redrawn from Skrjabin, 1964; from Jagerskiold, 1899)

Figure 5. Apophallus imperator, ventral view. (redrawn from Lyster, 1940)

Figure 6. Immature Apophallus americanus, ventral view. (original)

Figure 7. Apophallus bacalloti, ventral view. (redrawn from Timon-David, 1963) 

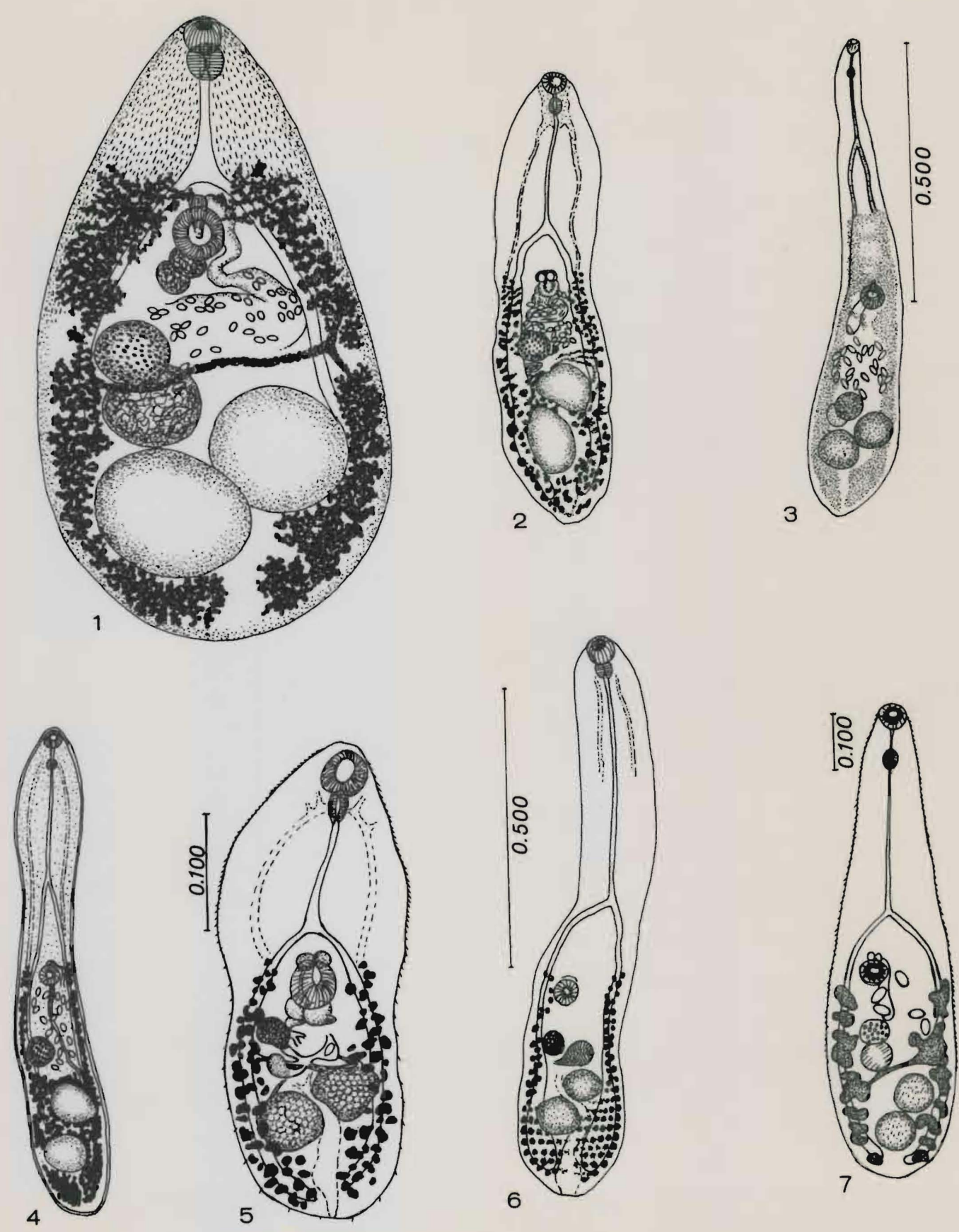
Figure 1. Apophallus zalophi, ventral view. (original)

Figure 2. Apophallus bacalloti, ventral view. (redrawn from Balozet and Callot, 1939)

Figure 3. Metacercaria of Apophallus itascensis, ventral view. (redrawn from warren, 1953)

Figure 4. Apophallus brevis, dorsal view. (original)

Figure 5. Apophallus venustus, ventral view. (original)

Figure 6. Apophallus crami, ventral view. (original) 

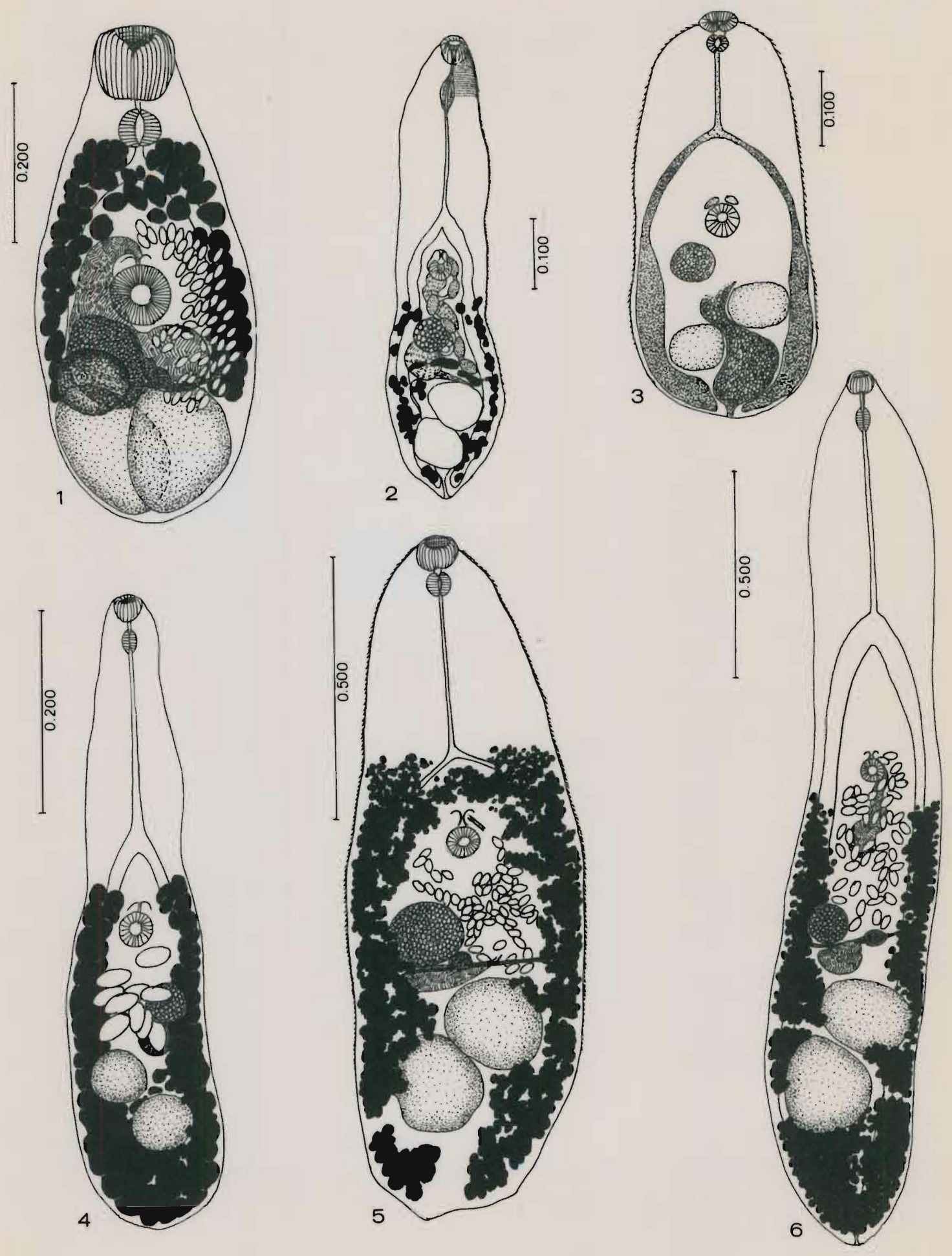


\section{TABLE I}

COMPARATIVE MEASUREMENTS OF ADULT APOPHALLUS SPP.

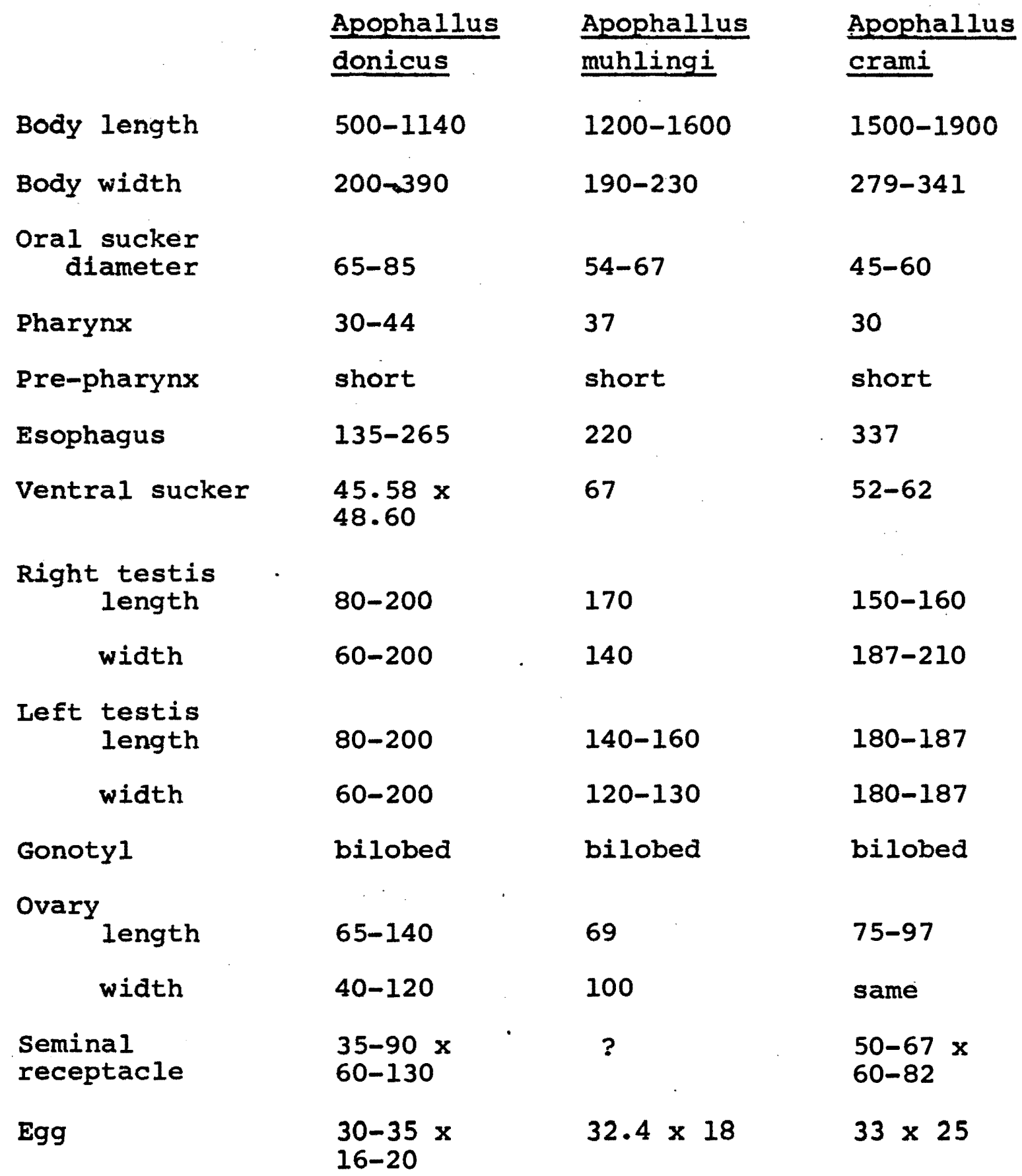


TABLE I (continued)

\begin{tabular}{|c|c|c|c|}
\hline & $\frac{\text { Apophallus }}{\text { bacalloti }}$ & $\begin{array}{l}\text { Apophallus } \\
\text { americana }\end{array}$ & $\frac{\text { Apophallus }}{\text { imperator }}$ \\
\hline Body length & $520-820$ & $900-1020$ & - \\
\hline Body width & -- & $\begin{array}{l}150-170 \text { Ant. } \\
200-210 \text { Post. }\end{array}$ & -- \\
\hline $\begin{array}{r}\text { Oral sucker } \\
\text { diameter }\end{array}$ & 42 & $50-60$ & $56-63$ \\
\hline Pharynx & 21 & $27-32$ & -- \\
\hline Pre-pharynx & 40 & none seen & very short \\
\hline Esophagus & 240 & very long & $\begin{array}{l}1 / 2 \text { body } \\
\text { length }\end{array}$ \\
\hline Ventral sucker & 40 & $35-55$ & $70-77$ \\
\hline $\begin{array}{c}\text { Right testis } \\
\text { length }\end{array}$ & (round) & -- & $57-63$ \\
\hline width & 75 & - & $112-126$ \\
\hline $\begin{array}{r}\text { Left testis } \\
\text { length }\end{array}$ & (round) & $-\infty$ & $57-63$ \\
\hline width & 84 & - & $112-126$ \\
\hline Gonotyl & bilobed & -- & bilobed \\
\hline $\begin{array}{l}\text { Ovary length } \\
\end{array}$ & (round) & -- & $26-31$ \\
\hline width & 44 & -- & $56-77$ \\
\hline $\begin{array}{l}\text { Seminal } \\
\text { receptacle }\end{array}$ & 50 & -- & - \\
\hline Egg & $\begin{array}{l}30-31 \times \\
18-19\end{array}$ & none & $\begin{array}{l}33-35 \times \\
14-19\end{array}$ \\
\hline
\end{tabular}


TABLE I (continued)

\begin{tabular}{|c|c|c|c|}
\hline & $\begin{array}{l}\text { Apophallus } \\
\text { itascensis }\end{array}$ & $\begin{array}{l}\text { Apophallus } \\
\text { major }\end{array}$ & $\begin{array}{l}\text { Apophallus } \\
\text { zalophi }\end{array}$ \\
\hline Body length & $405-903$ & $\begin{array}{l}\text { no figures } \\
\text { available }\end{array}$ & 435 \\
\hline Body width & $195-300$ & -- & $215-263$ \\
\hline $\begin{array}{l}\text { Oral sucker } \\
\text { diameter }\end{array}$ & $39-60$ & -- & $60-75$ \\
\hline Pharynx & $24-26$ & -- & $29-33$ \\
\hline Pre-pharynx & short & -- & $30-33$ \\
\hline Esophagus & $1 / 3-1 / 2$ body & - & 18 \\
\hline Ventral sucker & $37-48$ & -- & $52-60$ \\
\hline $\begin{array}{l}\text { Right testis } \\
\text { length }\end{array}$ & $73-95$ & -- & $81-96$ \\
\hline width & $93-119$ & -- & $81-100$ \\
\hline $\begin{array}{l}\text { Left testis } \\
\text { length }\end{array}$ & $73-95$ & -- & $81-96$ \\
\hline width & $93-119$ & -- & $81-100$ \\
\hline Gonoty I & bilobed & -- & bilobed \\
\hline $\begin{array}{l}\text { ovary } \\
\text { length }\end{array}$ & $51-73$ & -- & $55-75$ \\
\hline width & (round) & -- & $67-92$ \\
\hline $\begin{array}{l}\text { Seminal } \\
\text { receptacle }\end{array}$ & -- & - & 44 \\
\hline Egg & none & -- & $33 \times 18$ \\
\hline
\end{tabular}


TABLE I (continued)

\begin{tabular}{|c|c|c|c|}
\hline & $\frac{\text { Apophallus }}{\text { lerouxi }}$ & $\frac{\text { Apophallus }}{\text { venustus }}$ & $\frac{\text { Apophallus }}{\text { brevis }}$ \\
\hline Body length & $850-930$ & $950-1450$ & $600-900$ \\
\hline Body width & $168-172$ & $250-550$ & $130-260$ \\
\hline $\begin{array}{l}\text { Oral sucker } \\
\text { diameter }\end{array}$ & $24-26$ & 60 & $30-50$ \\
\hline Pharynx & $16-18$ & -- & $20-28$ \\
\hline Pre-pharynx & $31-36$ & - & 20 \\
\hline Esophagus & $123-144$ & -- & -- \\
\hline Ventral sucker & $33-37$ & 60 & $35-55$ \\
\hline $\begin{array}{c}\text { Right testis } \\
\text { length }\end{array}$ & $74-90$ & $150-200$ & $45-120$ \\
\hline width & $74-90$ & $150-120$ & $45-145$ \\
\hline $\begin{array}{l}\text { Left testis } \\
\text { length }\end{array}$ & $70-82$ & $150-200$ & $45-120$ \\
\hline width & $70-82$ & $150-200$ & $45-145$ \\
\hline Gonotyl & $?$ & bilobed & bilobed \\
\hline 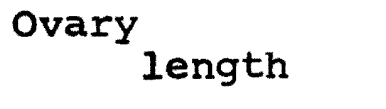 & 74 & 150 & $60-90$ \\
\hline width & 74 & 100 & $50-80$ \\
\hline $\begin{array}{l}\text { Seminal } \\
\text { receptacle }\end{array}$ & - & - & $40-80$ \\
\hline Egg & $29 \times 17$ & $\begin{array}{l}26-32 \times \\
18-22\end{array}$ & $\begin{array}{l}36-40 \times \\
16-22\end{array}$ \\
\hline
\end{tabular}


TABLE II

LIFE CYCLES OF EACH SPECIES OF THE GENUS APOPHALLUS

Species

Definitive Hosts

Snail Host

Second Intermediate Host

Source

Apophallus stizostedion vitreum, -- $\quad$ (may be minnows)

Van Cleave

americanus

.

$\begin{array}{ll}\text { Apophallus } & \text { duck (exp.) } \\ \text { bacalloti } & \text { canary (exp.) }\end{array}$

$-$
Gambusia affinis holbrooki

Girard, Botaurus stellaris

L.

and Mueller

(1932)

-

Apopha1lus

brevis

$\frac{\text { Gavia }}{\frac{\text { Larus }}{\text { domester }}} \frac{\frac{\text { Amnicola }}{\text { delawarensis }}}{\text { ic cats (exp.) }}$

fresh water fish, trout

Ransom (1920)

Lyster (1939)

domestic cats (exp.)

Price (1932)

rats.

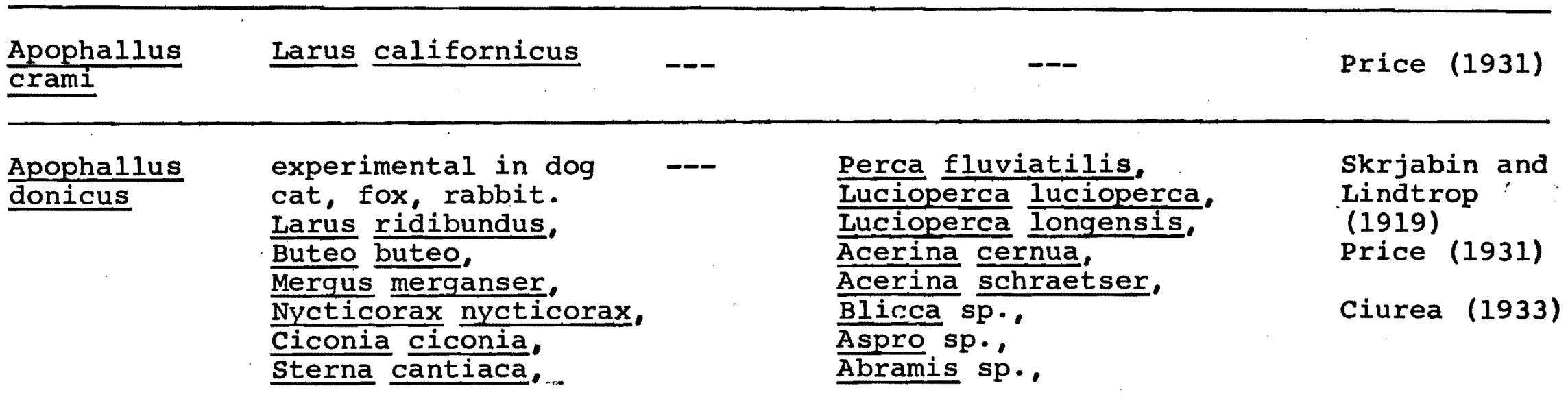


TABLE II (continued)

\begin{tabular}{|c|c|c|c|c|}
\hline Species & Definitive Hosts & Snail Host & Second Intermediate Host & Source \\
\hline & $\begin{array}{l}\text { Asio sp. } \\
\text { Turtur sp., } \\
\text { Columba sp., }\end{array}$ & & $\begin{array}{l}\text { Lucioperca sp., } \\
\frac{\text { Scardinius }}{\text { Gobio sp. }}\end{array}$ & \\
\hline & $\begin{array}{l}\text { experimental in } \\
\text { Homo sapiens, } \\
\text { cat, chicken, } \\
\text { gerbil, white rat, } \\
\text { golden hamster, } \\
\text { Ictalurus punctatus }\end{array}$ & $\frac{\text { Flumenicola }}{\text { virens }}$ & $\begin{array}{l}\text { Catastomus macrocheilus, } \\
\text { Salmo gairdneri, } \\
\text { Oncorhynchus kisutch, } \\
\text { Ptychocheilus oregonensis, } \\
\text { Rhinichthys osculus nubilus, } \\
\text { Richardsonius balteatus }\end{array}$ & $\begin{array}{l}\text { Niemi and } \\
\text { Macy (1973) }\end{array}$ \\
\hline
\end{tabular}

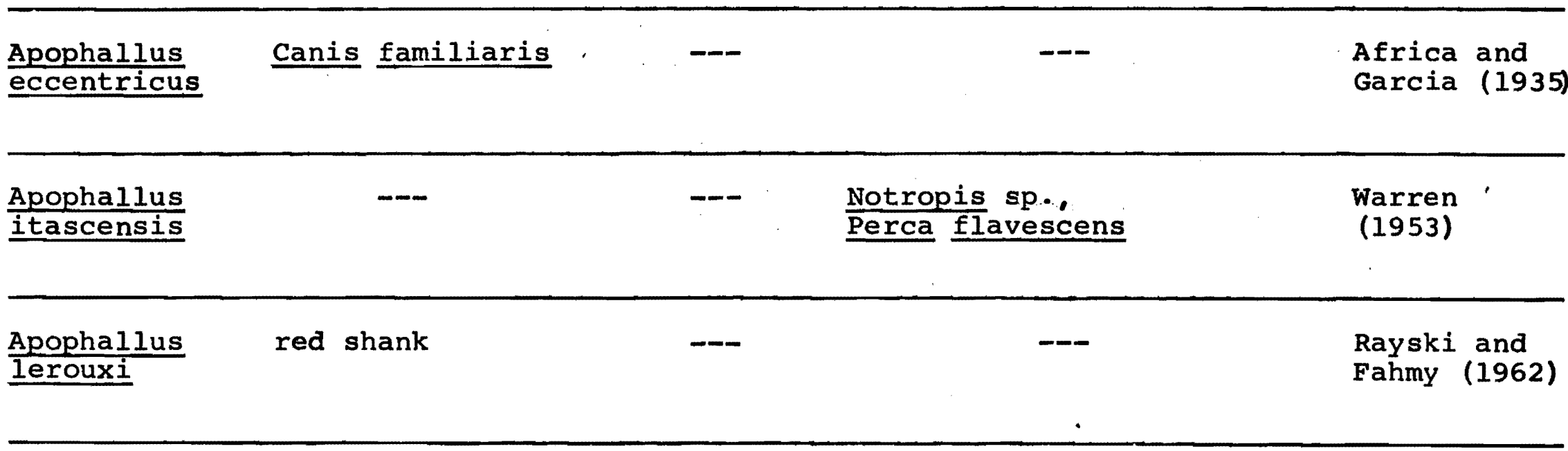


TABLE II (continued)

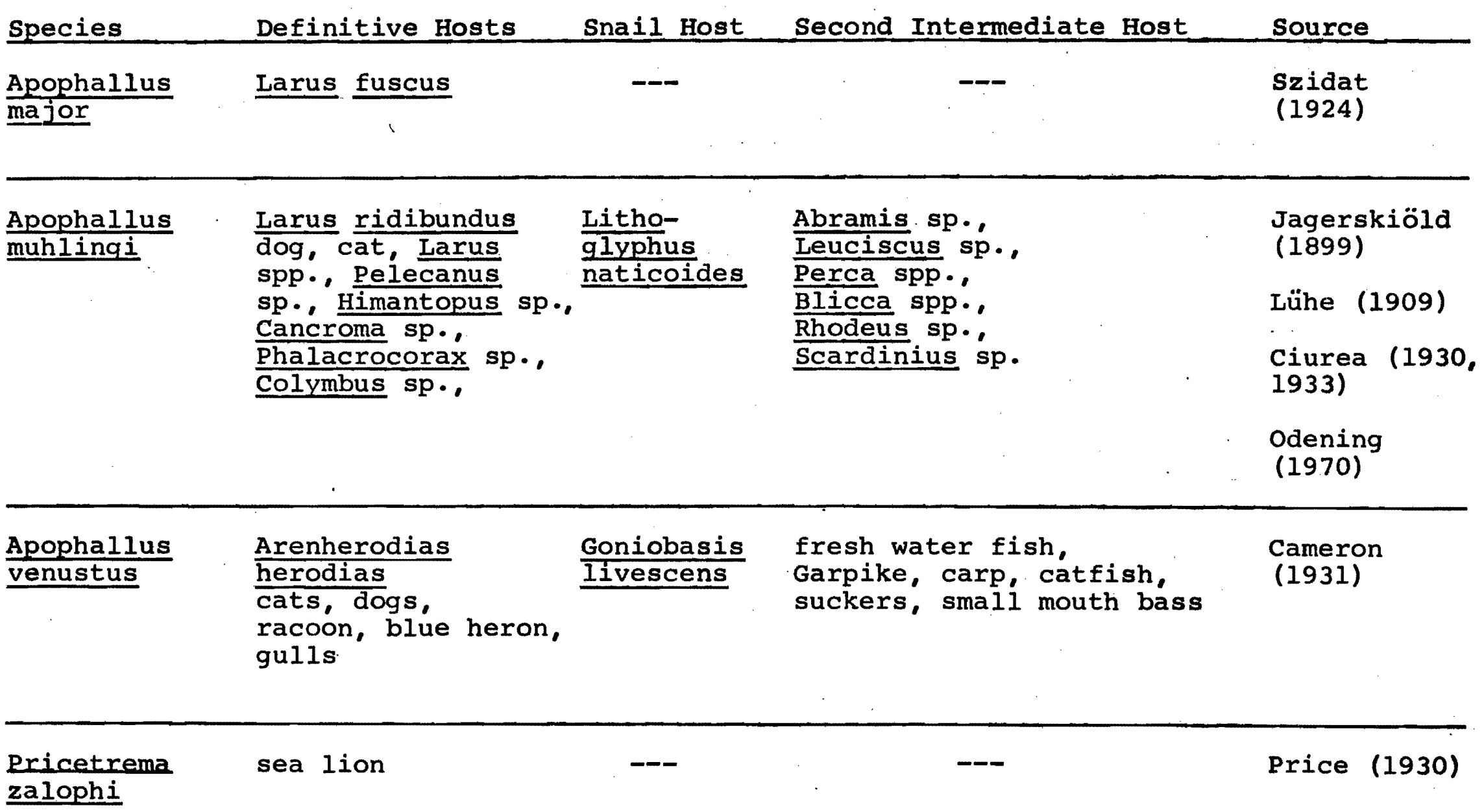


MATERIALS AND METHODS

COLLECTING FISH

Fish were collected in several ways. Small species which live along the banks under overhanging vegetation were collected with a Needham rake. This tool is scraped across the bottom of a stream and up the banks. It is then quickly raised out of the water, which drains rapidly off through the screen in its bottom, and the fish are left to be dumped into a suitable container.

Larger fish were collected with a fifteen foot net which had poles on each end. One man would stand stationary near shore and another man holding the other end of the net would describe an arc around him to another point on shore. The net was then carefully raised out of the water and the trapped fish were removed by hand. This method proved the most valuable in collecting specimens.

Another method used for all sizes of fish was a shocking device. Two men would hold a net stationary across a stream while a third would start at a point upstream, using a gasoline powered electric generator mounted on his back, and two long electrodes, which were placed in the water, to stun the fish with an electrical shock. The fish would float downstream into the net and were thus 
trapped.

All collecting was conducted in shallow water, never over five feet deep. On several occasions wet suits were used, but usually hip boots were sufficient.

\section{COLLECTING SNAILS}

Snails were collected almost exclusively with a Needham rake. On a very few occasions, due to a rocky bottom or encumbering vegetation, snails were collected by hand. Flumenicola virens seems to prefer muddy or sandy bottoms and relatively still water. In most instances, then, it was very easy to collect them. .

TRANSPORTING FISH AND SNAILS FROM THE FIELD TO THE LABORATORY

With small fish and snails plastic cake pans 10 inches in diameter were used for transport to the laboratory. These were filled half full with water and Otabs (Pemble Laboratories, River Falls, Wisconsin) were added to oxygenate the water. The cake pans were covered and placed in styrofoam soft-drink coolers to which crushed ice had been added.

With larger fish, or with large numbers of small fish, the styrofoam coolers were used alone. They were filled half full of water and otabs were added according to the number of fish present. Crushed ice was periodically placed directly in with the fish to maintain a relatively constant temperature. These methods proved quite reliable 
and there was normally less than 58 mortality of captured fish during transport to the laboratory. One instance where large numbers of fish died, however, occurred after reaching the laboratory. Aquaria filled with improperly dechlorinated water were used and there was almost complete mortality of the specimens.

\section{MAINTAINING ANIMALS IN THE LABORATORY}

In the laboratory fish were placed in aquaria which were filled with dechlorinated tap water, aerated by pumps, and kept at $12^{\circ} \mathrm{C}$. The aquaria were partially submerged in soft drink coolers to maintain this temperature. The water was dechlorinated by keeping it overnight in large, open containers. Fish were kept in this manner, without food, for as long as two months.

Snails were kept in plastic pans or aquaria, without aerators, in a coldroom at $6^{\circ} \mathrm{C}$. Uncrowded snails thus maintained lived up to two or more months.

At the beginning of the experiments, I obtained fifty $8 \mathrm{~cm}$ long salmon parr from the Bonneville Fish Hatchery. These were placed in a fifty gallon tank of dechlorinated tap water which rested in the bottom of a soft drink cooler. The cooler maintained a constant temperature of $12^{\circ} \mathrm{C}$. The tank was aerated and the fish were fed a special mixture of fish meal and vegetable meal which the hatchery uses for their fish. 
When fish were to be used for experiments with cercariae, they were slowly brought up to $17^{\circ} \mathrm{C}$ to avoid temperature shock and placed in an environmental chamber in 10" diameter cake pans half full of water. As long as no more than 2 salmon were placed in each cake pan, no oxygenation was necessary.

\section{OBTAINING METACERCARIAE}

All fish obtained were keyed to species and a record was kept of their numbers, species, and size. They were carefully examined for cysts while still alive. Every fish which was killed before being fed to laboratory animals was completely examined for parasites. Parasites found were killed, flattened, preserved, stained, mounted, and recorded.

Two methods were used for infecting laboratory animals. One involved feeding whole or parts of fish to animals such as cats and rats which would readily eat them. This was done when no particular calculation of numbers of cysts eaten was necessary.

The normal method used was to digest the fish and count metacercariae. The fish were killed by pithing, weighed, and then ground with a meat grinder. The ground fish were placed in a digesting solution of 0.58 pepsin and allowed to digest for about an hour at $37^{\circ} \mathrm{C}$ with gentle agitation using a magnetic stirer. This solution was then 
strained and diluted with $0.85 \%$ saline. This diluted digest was placed in a separatory funnel and the residue was removed after 15 minutes; this material was rinsed again in the same manner and the residue was collected in a watch glass.

Under a dissecting microscope the cysts were separated according to morphology and dimensions. Each type of cyst was kept in $0.85 \%$ saline for infecting laboratory animals.

INFECTING LABORATORY ANIMALS WITH METACERCARIAE

Most laboratory animals were force-fed concentrated and counted metacercariae, using several variations of two basic methods. Animals which would voluntarily eat flesh were fed whole fish or fish parts.

When small animals were used, such as rats, mice, hamsters and gerbils, it was sometimes necessary to anesthetize them before force-feeding solutions of concentrated cysts. The time for administration of ether or chloroform was very critical. The time varied considerably with the species, or even individuals of one species, so that while anesthetizing animals it was necessary to watch their behavior very closeIy to know exactly when to discontinue the procedure and insure recovery.

After an animal was unconscious, a hypodermic syringe, especially adapted with a long, thin plastic tube on the 
needle holder, was used to suck up a counted quantity of cysts, and administer them. This was done by carefully opening the animal's mouth, putting the tube down its throat, and squirting the cysts directly into its stomach. Care was taken to use a minimum quantity of solution with the cysts in order to reduce the possibility of regurgitation. Speed was essential in case of early recovery of the animal in order to avoid damage to the tube and to the experimenter.

Chickens were force-fed with this syringe without being anesthetized. A small quantity of tap water was forced in after the cysts to insure that they would reach the crop.

The human infection was administered by placing a known number of cysts in a gelatin capsule and swallowing it with a glass of water. Infection was verified by saving fecal samples and studying them for eggs.

Catfish were trained to come to the top of the water in their aquarium and hold their mouths open for food, usually bread or meat. It was then easy to drop a gelatin capsule full of cysts into these open mouths.

Usually, cats, gerbils, chickens and rats would readily eat whole or parts of fish. With rats and gerbils, however, sometimes it was necessary to put live fish in with them. When the fish would thrash around, the animal would pounce on it, kill it, and proceed to eat it. 
After infection the animals were kept in cages with both food and water. In some of the experiments, food was varied to see if this would affect the course of the infection. Rats, for instance, were sometimes kept on a diet of uninfected fish after the initial infection, instead of their normal cereal diet.

Fecal samples were periodically collected from infected animals and were washed with $0.85 \%$ saline solutions and strained through screens with known sized openings. The sediment was then washed and concentrated in separatory funnels. This sediment was carefully examined for eggs, using first the dissecting microscope and then the compound microscope.

EXAMINING SNAILS FOR CERCARIAE

Two methods were used in attempts to find the correct cercariae for Apophallus donicus. One method involved the crushing of snails with a light hammer or a pliers, picking away the shell fragments with dissecting needles, and placing the snail tissue in $0.7 \%$ saline solution. The digestive gland of the snail was teased apart to expose rediae and cercariae.

The other method was to put individual snails in petri dishes of water in an environmental chamber, kept at $17^{\circ} \mathrm{C}$ and set for regular periods of light and darkness. The chamber was kept warmer than the stream and cercariae 
readily left the snails under these conditions. Live cercariae were examined under the compound microscope.

\section{INFECTING FISH WITH CERCARIAE}

After the original, naturally infected fish were found, it became evident that I would have to determine which cercariae, of the eight to ten species found in Crystal Springs, were responsible for the cysts in the fish. By letting hundreds of snails shed cercariae, and by crushing hundreds of others of the three snail species from Crystal springs, it was determined that at least three species of heterophid cercariae were found in F. virens from this locality. By exposing non-infected fish to each of these species of cercariae and feeding the resulting metacercariae to laboratory animals, it was possible to implicate the particular cercariae which produced adult Apophallus donicus. The other two cercariae were probably Eurhelmis cotti n. sp., Simon and Macy (unpublished), and another probably undescribed species of the genus Apophallus.

After the cercariae which produced $\underline{A}$. donicus were found and identified, it was easy to find a snail shedding this exact type of cercariae and examine the rediae which were inside the snails' digestive glands. Then, using one particular snail as a source of infection for fish, and for developmental stages, all of the early life cycle was definitely established and finally connected with adult $\underline{A}$. doni- 
cus.

When infecting fish, numbers of cercariae were approximated and placed in a petri dish of dechlorinated water kept at $17^{\circ} \mathrm{C}$ by a water bath. The cyst-free fish were put in with the cercariae for a particular length of time and removed to the environmental chamber which was also set at $17^{\circ} \mathrm{C}$. Here they stayed and were fed each day until the cysts formed by the cercariae were infective. It was found that after 4 weeks at this temperature the metacercariae would grow into adult A. donicus if fed to laboratory animals.

Other similarly infected fish were slowly lowered in temperature and then placed into a cold room at $6^{\circ} \mathrm{C}$. The metacercariae in these fish were not infective even after 9 weeks.

Another method used to obtain heavy infections was to put one heavily shedding snail in an aquarium with several fish over a period of several weeks. Each day the fish were infected by more cercariae. At the end of the period of infection the snail was retrieved, opened, and the rediae stages were preserved in AFA or Gilson's fluid.

To insure that the coho salmon and Gambusia spp. used in these experiments were free of previous infections, one half of the total number of each species was either fed whole to laboratory animals, or digested with acid pepsin. On no occasion was any previous infection found. 
During or after each infection by cercariae, samples of cercariae were killed and preserved in hot AFA, and rediae stages from the snail were killed and preserved in AFA or Gilson's fluid. Later, all of these specimens were stained and mounted on slides.

EXCYSTING OF METACERCARIAE

Metacercariae obtained from the acid pepsin digestion of fish were excysted either mechanically or chemically. Enzymatic excystation techniques were most effective to obtain the metacercariae (Macy et. al., 1967). This was because the nature of the cyst wall and the small size of the cysts made mechanical excystation very difficult.

Metacercariae were placed in $0.85 \%$ saline after excystation and studied alive. A few were flattened, fixed with Gilson's solution, stained with Erhlich's acid hematoxylin, and mounted on slides. Some excysted metacercariae were kept living in $0.85 \%$ at $6^{\circ} \mathrm{C}$ for up to three days. OBTAINING CULTURES OF UNINFECTED SNAILS

Flumenicla virens snails were collected in the summer when they were laying eggs. A number of adults were placed in a suitable, aerated aquarium. The adults layed many eggs on the sides of the aquarium. Adults were then removed. In about two weeks young snails hatched, and these were raised to feed on eggs from adult $\underline{A}$. donicus. 
ATTEMPTS TO INFECT FLUMENICOLA VIRENS WITH EGGS

A number of eggs were collected from adult $\underline{A}$. donicus and placed in distilled water. This was a difficult process because $\underline{A}$. donicus specimens have very few eggs in the uterus at any one time. Large numbers of adults were placed in distilled water and high salt solutions alternately to cause them to shed their eggs.

When about two hundred eggs were collected young laboratory-reared snails were placed with the eggs in dechlorinated tap water for several days. After it appeared that eggs had been eaten, the snails were placed in a separate aquarium.

\section{SHEDDING EXPERIMENTS}

When snails were checked for shedding times, a sizeable group of snails shedding the proper cercariae were found by methods already discussed. Then this sample was put individually in an environmental chamber set at a constant $17^{\circ} \mathrm{C}$, and with a period of light and darkness simulating a normal spring day and night. Each hour after the snails were put in the chamber, for 24 hours, each snail was examined for shedding with a dissecting microscope, and if any occurred, the snail was transferred to a new petri dish of water.

After the snails were removed from the dishes, the cercariae were killed by adding $95 \%$ ethanol to the water 
to facilitate counting. At this time it was found that cercariae of $\underline{A}$. donicus could withstand $5 \%$ ethanol for 3-5 hours before dying. Counting was done by placing the petri dish over a grid and counting cercariae in each square.

\section{MICROSCOPIC PREPARATIONS}

All adults, metacercariae, and rediae were killed and fixed with either Gilson's fluid or AFA under a cover glass on a microscope slide. This method would sometimes distort or crush the internal organs of adults and cause rediae to burst open if enough pressure was applied to flatten the specimens sufficiently for a good slide. In the case of the adult, this was because the anterior half of the body is flattened dorso-ventrally and the posterior half is almost cylindrical. This difference in thickness caused many problems with flattening the specimens. The rediae broke open only because they are extremely fragile.

Cercariae were not flattened at all. They were pipetted live into hot AFA. This killed them immediately and helped keep their natural shape.

All specimens were stained with Erhlich's acid hematoxylin and mounted on microscope slides. When cercariae were examined alive under the compound microscope, neutral red and nile blue stains were sometimes used to show up certain structures. 
Material which was sectioned from the adults and metacercariae encysted in a coho salmon tail fin were fixed in picric acid. Sections were made 6 in thickness from parafin mounted tissues and these were applied to slides and stained with Erhlich's acid hematoxylin. 


\section{DISCUSSION AND CONCLUSIONS}

In this paper Apophallus donicus is redescribed from Oregon specimens, its life cycle is outlined, and some significant additions are made to its biology. No detailed study has been made of its occurrance nor its effect on game fish in the wild. It is prevalent in the areas where infected fish were found, and therefore the natural definitive hosts in the area must be heavily infected. This would no doubt cause them some discomfort or even eventual death. Africa, et. al. (1935b, 1935c, 1940) showed that in heavy infections of humans by heterophyids, coronary malfunction could result from eggs accumulating in the blood vessels of the heart. Other serious possible effects include perforations of the intestines with subsequent infections, and central nervous system problems due to accumulation of eggs in vital blood vessels in the brain.

Human infections are probably rare in Northwestern United States because fish is usually cooked quite well before it is eaten. Also, in larger fish, like salmon, the skin is usually not eaten. There is a possibility that smoked or salted fish could contain some viable cysts. No study was made on the susceptability of this trematode to salt.

I am definitely in agreement with Price (1931) and 
Yamaguti (1971), who think that this species is a member of the genus Apophallus. No specific attempts have been made to reclassify the species of the genus Apophallus or to make a key to the species. This is because work is underway with a possible new species of this genus, and when this is done, a thorough examination of taxonomy will be attempted. 


\section{REFERENCES}

Africa, C. M. and Garcia, E. Y. 1935a. Two more new heterophyid trematodes from the Philippines. Philippine J. Sci. 57:443-448.

Garcia, E. Y., and de Leon, W. 1935b. Intestinal Heterophyidae with cardiac involvement. A contribution to the etiology of heart failures. Philippine J. Public Health. 2:1-22.

de Leon, W., and Garcia, E. Y. 1935c. Heterophidiases. II. Ova in sclerosed mitral valves with other lesions in the myocardium. Philippine Is. Med. Assocn. 15:583-592.

- Garcia, E. Y., and de Leon, W. 1940. Visceral complications in intestinal heterophyidiases of man. III. International Congr. Microbiol. (New York Rep. Proc.) : 447-449

Balozet, I. and Callot, J. 1939. Trématodes de Tunisie. superfamille Heterophyiodea. Arch. Inst. Pasteur Tunis. 28:34-63.

Cameron, T. W. M. 1936. Studies on the heterophyid trematode, Apophallus venustus (Ransom, 1920) in Canada. Part I. Morphology and Taxonomy. Can. J. Research. D,14:59-69.

- 1937a. Studies on the heterophyid trematode Apophallus venustus (Ransom, 1920) in Canada. Part II. Life history and bionomics. Can. J. Research. $D, 15(2): 38-51$.

- 1937b. Studies on the heterophyid trematode Apophallus venustus (Ransom, 1920) in Canada. Part III. Further hosts. Can. J. Research. D, 15:275.

Ciurea, I. 1924. Heterphyidés de la faune parasitaire de Roumanie. Parasitology. 16:1-21.

- 1928. Rossicotrema donicum skrjabin et Lindtrop et sa metacercaire. Arch. Roumaines Path. Exper. Microbiol. 1:531-540.

- 1933. Les vers parasites de I'homme, 
des mammiferes et des oiseaux provenant des poissons du Danube et de la mer Noire. Arch. Roumaines Path. Exper. Microbiol. 6:5-135.

Hsï, H. F. 1936. Uber das exkretionssystem von Rossicotrema donicum Skrjabin, 1919 (Trematoda).

2. Parasitenk. $8: 116-120$.

Jagerskiöld, L. A. 1899. Distomum lingua Creplin, ein genitolnapftragendes Distomum. Bergens Mus. Aarb. (1898). 2:1-16.

Looss, Arthur. 1899. Weitere beiträge zur kenntniss der trematoden-fauna Aegyptens, zugleich versuch einer natürlichen gliederung des genus Distomum Retzius. Zool. Jahrb., Jena, Abt. F. Syst. 12: . 521-784.

Lühe, M. 1909. Parasitische plattwurmer. I. Trematoden. Susswasserfauna Dentschl. 17:1-217.

Lyster, I. L. 1940. Apophallus imperator sp. nov., a heterophyid encysted in trout, with a contribution to its life history. Can. J. Research. D (18) $3: 106-121$.

Macy, R. W. Berntzen, A. K. and Benz, Mary. 1967. In vitro excystation of Sphaeridiotrema globulus metacercariae, structure of cyst, and the relationship to host specificity. J. Parasitol. $54: 28-38$.

Miller, M. J. 1940. Black spot in fishes. Can. J. Comp. Med. Vet. Sci. 4:303-305.

- 1941. The life history of Apophallus

brevis Ransom, 1920. J. Parasitol. Suppl. 27:7.

- 1942. Black spot disease of speckled trout. Rev. Can. Biol. 1:464-471.

1946. The cercaria of Apophallus brevis. Can. J. Research. 24 (D) $2: 27-29$.

Morosov, F. N. 1952. Superfamille Heterophyoidea Faust 1929 in Skrjabin, K. I., Trematodes des animaux et de l'homme (en russe) 4:229-615.

Odening, Klaus. 1970. Der entwicklungszyklus von Apophallus muhlingi (Trematoda: Opisthorchiida: Heterophyidae) in Berlin. Z. Parasjtenk. 33:194-210.

Price, Emmet W. 1931. A new species of trematode of the 
family Heterophyidae, with a note on the genus Apophallus and related genera. Proc. U. S. Nat. Mus. 79:1-6.

- 1933. The trematode parasites of marine mammals. Proceedings of the U. S. Nat. Mus. 8I: (13) $: 1-67+12$ plates.

Ransom, B. H. 1920. Synopsis of the trematode family Heterophyidae with descriptions of a new genus and new species. Proc. U. S. Nat. Mus. 57:527573 .

Rayski, C. and Rahmy, M. A. M. 1962. Investigations on some trematodes of birds from east scotland. zeit. fur Parasitenk. 22:186-195.

Simon, Michael Joseph, and Macy, Ralph W. Euryhelmis cotti n. sp. (Trematoda: Heteraphyidae) with observations on its life cycle. Unpublished.

skrjabin, K. and Lindtrop, G. 1919. Trematodes intestinales des chiens du Don. Isvest. Donsk. Vet. Inst. $1: 1-17$.

szidat, I. 1924. Beiträge zur kenntniss ostpreussischer trematoden. Beitrage aus tierkunde, widmungeschrift für geheimrat Prof. Dr. M. Brawn, in Pr., Juli 1924, p. 1-6 du triage a part. planche $I$.

Timon-David, J. 1963. Developpement expérimental d'un trématode du genre Apophallus Luhe (Digenea, Heterophyidae). Bull. Soc. Hist. Nat. Toulouse. 98:452458 .

Van Cleave, H. J. and Mueller, J. F. 1932. Parasites of Oneida Lake fishes. Part I. Descriptions of new genera and new species: Roos. Wildl. Ann. 3:1-72.

Warren, B. H. 1953. A type of metacercarial cyst of the genus Apophallus from the perch, Perca flavescens, in Minnesota. Amer. Midl. Nat. 50(2):397-401.

Witenberg, G. 1929. Studies on the trematode family Heterophyidae. Ann. Trop. Med. 23:121-230.

- 1930. Corrections to my paper: Studies on the trematode family Heterophyidae. Ann. Mag. Nat. Hist. Ser. 10, 5:412-414. 